https://helda.helsinki.fi

\title{
Cyanobacteria as a Source for Novel Anti-Leukemic Compounds
}

\section{Humisto, Anu}

2015

Humisto , A, Herfindal , L , Jokela , J , Karkman , A, Bjørnstad, R, Choudhury , R R \&

Sivonen , K 2015 , ' Cyanobacteria as a Source for Novel Anti-Leukemic Compounds ',

Current Pharmaceutical Biotechnology , vol. 17 , no. 1 , pp. 78-91 . https://doi.org/10.2174/13892010166661508261

http://hdl.handle.net/10138/307572

https://doi.org/10.2174/1389201016666150826121124

cc_by_nc

acceptedVersion

Downloaded from Helda, University of Helsinki institutional repository.

This is an electronic reprint of the original article.

This reprint may differ from the original in pagination and typographic detail.

Please cite the original version. 


\title{
Cyanobacteria as a Source for Novel Anti-Leukemic Compounds
}

\author{
Anu Humisto ${ }^{a}$, Lars Herfindal ${ }^{b}$, Jouni Jokela ${ }^{a}$, Antti Karkman ${ }^{\mathrm{a}}$, Ronja Bjørnstad ${ }^{\mathrm{b}}$, Romi Roy Choudhury ${ }^{\mathrm{b}}$ \\ and Kaarina Sivonen ${ }^{* a}$
}

\begin{abstract}
${ }^{a}$ Department of Food and Environmental Sciences, Division of Microbiology and Biotechnology, University of Helsinki, Helsinki, Finland; ${ }^{b}$ Department of Biomedicine, University of Bergen, Bergen, Norway
\end{abstract}

\begin{abstract}
Cyanobacteria are an inspiring source of bioactive secondary metabolites. These bioactive agents are a diverse group of compounds which are varying in their bioactive targets, the mechanisms of action, and chemical structures. Cyanobacteria from various environments, especially marine benthic cyanobacteria, are found to be rich sources for the search for novel bioactive compounds. Several compounds with anticancer activities have been discovered from cyanobacteria and some of these have succeeded to enter the clinical trials. Varying anticancer agents are needed to overcome increasing challenges in cancer treatments. Different search methods are used to reveal anticancer compounds from natural products but cell based methods are the most common. Cyanobacterial bioactive compounds as agents against acute myeloid leukemia are not well studied. Here we examined our new results combined with previous studies of anti-leukemic compounds from cyanobacteria with emphasis to reveal common features in strains producing such activity. We report that cyanobacteria harbor specific anti-leukemic compounds since several studied strains induced apoptosis against AML cells but were inactive against non-malignant cells like hepatocytes. We noted that particularly benthic strains from the Baltic Sea, such as Anabaena sp., were especially potential AML apoptosis inducers. Taken together, this review and re-analysis of data demonstrates the power of maintaining large culture collections for the search for novel bioactivities, and also how anti-AML activity in cyanobacteria can be revealed by relatively simple and lowcost assays.
\end{abstract}

Keywords: apoptosis, acute myeloid leukemia, Baltic Sea, bioactive compounds, cyanobacteria, hepatocyte, Molm13, IPC-81

\section{INTRODUCTION}

Most, if not all leukemia patients, and particularly those with acute myeloid leukemia (AML) rely on heavy chemotherapy to control the disease in the initial phase of the therapy (induction remission therapy). Despite intensive research to develop novel chemotherapy, most AML patients receive treatment regimens developed several decades ago [1]. The majority of drugs in use today, including the preferred anti-AML drug daunorubicin (DNR) originate from natural compounds, and microbes from the entire biosphere continue to be the major source of these valuable compounds [2-4]. Marine organisms are especially interesting; while oceans cover most of the earth`s surface, the terrestrial environment has so far been the most explored with respect to bioactive compounds.

Cyanobacteria are photosynthetic prokaryotes that are highly abundant and diverse in all aquatic and terrestrial environments $[5,6]$. The versatility of cyanobacteria is also seen in a wide variety of secondary metabolites that they produce [7], reflected by the diversity of bioactivities associated with these sometimes structurally complex molecules. Whereas some compounds are toxic and pose a direct health risk to humans and domestic animals, others have antifungal, antibiotic, antiviral activities, or selectively inhibit enzymes and functions in mammalian cells [4, 7-9].

*Address correspondence to this author at the Department of Food and Environmental Sciences, Helsinki University, P.O. Box 56: FI-00014, Helsinki, Finland; E-mails: kaarina.sivonen@ helsinki.fi

Cyanobacteria are, along with heterotrophic bacteria, the most potent organisms in marine environments producing bioactivities that can lead to pharmaceutical agents [10]. Cyanobacterial bioactive compounds include peptides, polyketides, peptide-polyketide hybrids, alkaloids and polysaccharide structures produced through ribosomal, nonribosomal, or hybrid pathways (Fig. 1) [11-13]. Moreover, each compound usually exists in several different variants, exemplified with the aeruginosin family, which nowadays includes over 50 variants differing in chemical structure and enzyme inhibition abilities [14, 15]. An intriguing feature of some cyanobacterial compounds is their ability to selectively induce cell death in human cancer cells. Anticancer compounds have been studied through different methods perhaps most commonly via cell based assays and a large number of different compounds with anticancer activity have been discovered until today. In the following section, we will give some examples of potent anticancer compounds isolated from cyanobacteria.

\subsection{Anticancer compounds from cyanobacteria}

Anticancer compounds from cyanobacteria affect the cells by different mechanisms of action, such as interruption of cytoskeletal structures, modulation of signaling pathways or enzymes, or interaction with DNA $[16,17]$. Dolastatins (Fig. 1), for instance affect cell division by disrupting the microtubule function [18]. Dolastatins were first isolated from sea hare Dolabella auricularia but were later found to be produced by the cyanobacteria Symploca sp. and Lyngbya majuscula, on which the sea hare feeds [19-21]. In the following years the highly potential antineoplastic compounds dolastatin 10 and 15 were discovered $[22,23]$ and they went through the first phases of clinical trials, but were discontinued due to severe side effects. Still, studies on dolastatin have continued and several improved synthetic 
analogs have been demonstrated. Brentuximab vedotin (Adcetris ${ }^{\circledR}$ ) is composed of monomethyl auristatin E, a synthetic analogue of dolastatin 10, and monoclonal antibody CD30. It has been approved by FDA to the treatment of Hodgkin`s lymphoma and anaplastic large cell lymphoma [24]. Other promising auristatin $E$ and antibody conjugates are also being evaluated in different phases of clinical trials [25].

Fig. 1. A selection of cyanobacterial anticancer compounds.

Another group of microtubule disruptors is the cryptophycins (Fig. 1). Cryptophycin A was isolated from Nostoc sp. GSV224 and it was found to exhibit anticancer activity toward several cancer cell types including multi-drug

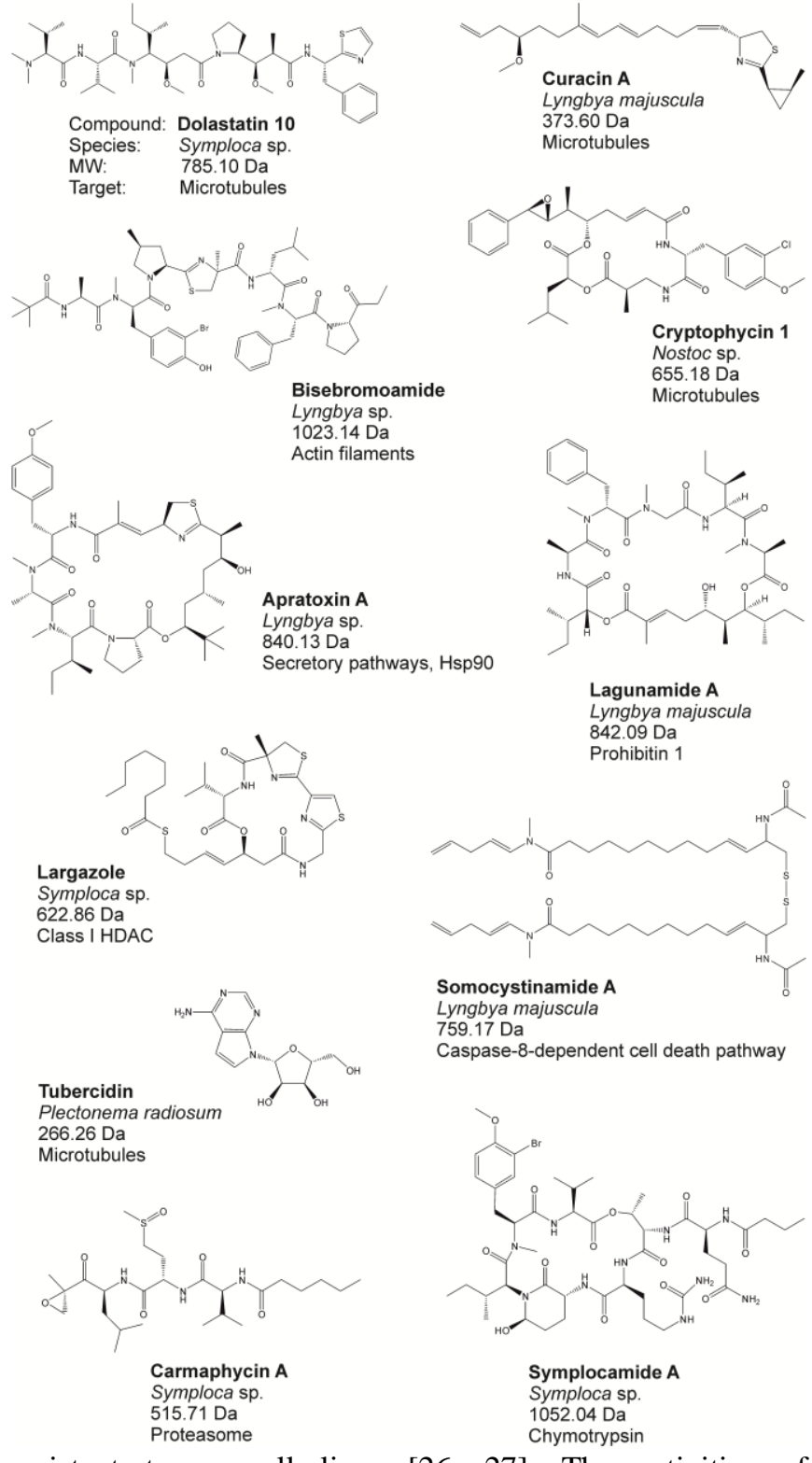

resistant tumor cell lines [26, 27]. The activities of cryptophycins were improved by constructing chemical analogs and cryptophycin-52 entered a clinical trial, but lacked efficacy in phase II studies [28]. More analogs are presented, together with targeting molecules, such as antibody conjugates [29, 30]. Curacin A (Fig. 1) is another compound affecting cell cycle via microtubulins [31]. It was found early in the 90's and was described toxic to brine shrimps and to be an antimitotic compound [32]. Despite some unfavorable properties, chemical modifications improving solubility and stability were made without affecting biological activity [33, 34]. The newly discovered bisebromoamide (Fig. 1) from Lyngbya sp. was shown to affect cell structure through interaction with actin filaments in a morphology profile study $[35,36]$. The first studies showed activity at nanomolar concentrations against a panel of human cancer cell lines and recently it was demonstrated to have apoptotic effect against certain renal cancer cell lines by inhibiting P13K/Akt/mTOR and Raf/MEK/ERK signaling pathways [35, 37].

Different Lyngbya species have been a rich source of anticancer compounds. Apratoxins (A-E) (Fig. 1) is another group of compounds collected originally from Lyngbya sp. harboring cytotoxic properties [38-40]. Apratoxin A was first described to cause cytotoxicity to human solid tumor cell lines. Later the range of the target cancer cell lines has been extended. Apratoxins were shown to inhibit several cancerassociated receptors in the secretory pathway but also target the heat shock proteins (Hsp 90) [41-43]. As with curacin A, the antitumor activity and selectivity of apratoxins were improved by hemisynthesis of analogs [44, 45]. Potential lipopetide somocystinamide A (Fig. 1) from L. majuscula can activate a caspase-8-dependent cell death pathway in tumor cell lines for instance in Jurkat cells [46, 47] and cyclodepsipeptide aurilide targets prohibitin 1 initiating apoptosis by mitochondrial-mediated pathways [48]. Aurilides and their naturally occurring variants such as lagunamides (Fig. 1) exhibit cytotoxic features against cancer cell lines [49-52]. In addition, lagunamides show potential antimalarial activity against Plasmodium falciparum $[51,53]$.

Largazole (Fig. 1) is an interesting cyanobacterial anticancer compound that inhibits class I histone deacetylases $[54,55]$. Inhibition of the histone deacetylases (HDAC) has become an attractive drug target particularly in cancer chemotherapy, and several HDAC inhibitors are used against AML [56]. Largazole was isolated from Symploca sp. from Key Largo, Florida and it showed strong selective activity against cancer cell lines [57, 58]. This compound is defined as prodrug, which is converted into active thiol compound. Several total syntheses and structural modifications of largazole have been performed, extending the target diseases from colorectal carcinoma and other cancers to osteoporosis, liver fibrosis, corneal neovascularization etc. [59-61]. Novel carmaphysins (A, B) (Fig. 1) exhibited nanomolar cytotoxicity to human lung adenocarcinoma and colon cancer cell lines in addition to inhibition to $20 \mathrm{~S}$ proteasome of Saccharomyces cerevisiae [62]. Further studies have been initiated on the total synthesis and to investigate proteasome inhibition complex [62, 63]. Symplocamide A (Fig. 1) has been identified as chymotrypsin inhibitor with cytotoxic 
features [64]. It shows nanomolar activity against lung cancer and mouse neuroblastoma cell lines. Symploca sp. from Papua New Guinea is producing symplocamide A and its total synthesis was described being the first solid phase synthesis of an aminohydroxypiperidone (Ahp) cyclodepsipeptide [64, 65].

There are in addition numerous anticancer compounds detected in cell-based assays where the exact mechanism of action is not yet identified. Dragonamide C and D from Lyngbya polychroa were reported to have weak antimitotic activity against osteosarcoma, colon adenocarcinoma and neuroblastoma cells [66]. Minutissamides A-D from Anabaena minutissima were described to have varying antiproliferative activity against human colon cancer cell line [67]. Recently a group of novel almiramides (D-H) was identified from Oscillatoria nigroviridis along with the known compound almiramide B [68]. The organic extracts showed promising activities but in further studies the compounds indicated only mild activity against human cancer cell lines and stronger activity against gingival fibroblast cell line used as an example of a primary cell line. The first almiramide molecules (A-C) were tested primarily against Leishmanias studying possible antiparasite effects but also these compounds showed cytotoxic effects on Vero cell line from monkey kidney [69]. Although the first cell based studies did not show significant selectivity, the modification of the structures may be a significant step in designing compounds with specific targets. Similarly the studies of the mechanism of action play a key role in improving the bioactivity. Lead compounds can be tested for properties with anticancer drugs to detect synergistic effects. Synergistic improvements have been described for instance in study where photosynthetic accessory pigment C-phycocyanin was tested with topotecan against prostate cancer cell lines and in other study where cyanobacterial crude extract and the anti AML-drug daunorubicin were tested against acute myeloid leukemia cell line [70, 71]. In conclusion, cyanobacteria remain a rich source for bioactive compounds with potential as anticancer drugs or leads, depicted by the high discovery rate of novel compounds. Developments of detection methods and sensitivity of instruments have brought improvements which have decreased the sample amount needed to detect and describe the active compounds and this hopefully hastens the study paths from potential natural extract to drug lead trough structure elucidation, total synthesis and unraveling the mechanism of action [10].

\subsection{Methods for screening cyanobacterial strains for anticancer activity}

During the last decades, screening programs for bioactive compounds from natural sources has driven the development of high-throughput methods, often in combination with advanced computational biology or bioinformatics [72]. Unfortunately, data from such large screening programs often remain unpublished, hindering any external evaluation of the methods behind the selection procedure, and more importantly, making it difficult to compare the screening results from different laboratories and culture collections. We will here give a brief introduction to some methods used to detect anticancer activity, and the type of information available with the different bioassays.

\subsubsection{Cell-based assays:}

Cell based assays are one of the most used to screen for anticancer compounds. Such assays have the advantage that they can be used in automated high-throughput screens, and a number of cell lines, relevant for different diseases are commercially available. In addition, several companies offer standardized screens on cell panels, and the National Institute of Health in the USA offers screens on 60 tumor and normal cell lines [75, 76]. Moreover, such assays allow for testing on primary cell lines as well as non-immortalized cell samples from patients $[77,78]$. A particular advantage with cell assays is that these are compatible with different types of samples, ranging from crude extracts to HPLC-fractions, or purified compounds. A selection of a few cell lines is often chosen to screen a whole culture collection [79-82] and selected extracts or purified compounds are scrutinized for anticancer effect on a large panel of cancer and normal cell lines [70, 83] often combined with chemical analyses of extract to find the compound of interest [84].

It is crucial to critically choose the methods used to record toxicity in cell based assays. Colorimetric assays like the tetrazolium-based assays for metabolic activity and assays to measure e.g. ATP-levels or conversion of pro-caspase-3 to caspase- 3 are widely used, and are compatible with automated high-throughput screens. However, any assay based on intensity of a light signal will be affected by the sometimes large quantity of pigments present in a crude extract, increasing the risk of false positive or negative results. The metabolic-based assays usually rely on reduction of a substrate, and if a toxin increases levels of reactive oxygen species (ROS) in a cell, this can create a higher turnover of substrate. In these instances, different methods must be considered. Microscopic analyses of cell populations give more information than colorimetric assays, such as the state of cells (necrotic, apoptotic, mitotic etc.) but will not be able to detect for instance growth inhibition. Moreover this is a cumbersome method, relying much on manual work. Although automated microscopes and software can aid in quantification, some cell lines and samples still demand manual assignment of cell morphology. Also, there are cases where the cell death cannot be recognized morphologically, which will produce false negatives [85]. Flow-cytometry based assays (like staining for apoptosis marker AnnexinV and the necrosis marker propidium iodide) is perhaps more costly than the previous methods, but can be automated to fit for instance 96-well plates. However, this method is also best suited with clean extracts or fractions, without particulates or remnants of sediments.

A general rule is that to be certain of cell death induction, two biochemically unrelated methods should be used. However during the initial screen for bioactivity, the main focus should be to eliminate negative fractions, and more emphasis should be put into the analyses in the secondary screens of selected fractions/extracts. There is a balance between quality of the data, and the quantity of samples or 
extracts to be analyzed. A particular problem arose when we screened benthic cyanobacterial extracts for antileukemic activity. A number of aqueous extracts were toxic to a selection of AML cell lines [70, 82], and a study on marine diatoms suggested that this could be due to adenosine-like activity [86]. Co-incubation of cells with cyanobacterial extracts and adenosine deaminase (ADA) eliminated the toxicity in many extracts, suggesting that the toxicity was an ADA-sensitive nucleotide [82]. AML-cells have been shown to be sensitive to adenosine through adenosine receptor 2 [86, 87]. A way to circumvent the adenosine-related toxicity was to use serum without heat inactivation in the cell medium [82]. The ADA present in the serum will then convert adenosineor toxic adenosine analogues to the inactive inosine or deaminated analogs.

\subsubsection{In vitro biochemical assays:}

Assays detecting a particular biochemical process, like enzyme activity, are commonly used when a particular drug target is identified. In modern drug development, this has become more popular, since genomic analyses of large patient cohorts make it possible to extract poor prognosis factors for instance in cancer therapy. This approach led to the discovery of the microtubulin-interacting compound tubercidin (Fig. 1) from cyanobacteria [88]. There are numerous of targets identified as particularly interesting for AML, including cell signal modulator like tyrosine kinases such as FMS-like tyrosine kinase 3 (FLT3), mammalian target of rapamycin (mTOR), Janus-associated kinase (JAK), or inhibitors of cell functions like proteasome, epigenetic regulators of gene expression (DNA methyltransferase), histone deacetylase, and disruptor of telomeric signaling-1, to mention a few [89]. In vitro assays measuring for instance enzyme activity fits well with an automated high-throughput program, with the ability to test several thousand samples and fractions within a short time-frame. A drawback, however, is that when searching for anticancer compounds, there is a risk that anticancer compounds acting on different proteins will not be detected. Again, one has to balance the benefits of highthroughput assays to the quality of data using more highcontent-focused assays.

In silico screen to find structural related compounds or drug targets emerge as a powerful tool to identify drug candidates. For this, one needs an identified target, a structure, a scaffold, or the pharmacophor model of an active compound. Moreover, a chemical compound-library is needed. This last point may restrict the usefulness of cyanobacterial compound libraries, since they do not have the same number of compounds compared to commercially available compound libraries. Moreover, the complexity of many cyanobacterial secondary metabolites with their numerous different conformers makes it difficult to get reliable docking data with a high-throughput virtual screen. Still, El-Elimat and coworkers [90] compared secondary metabolites from cyanobacteria with anticancer compounds with focus on nine sets of chemical properties, showing that cyanobacterial compounds partly aligned well with FDA-approved anticancer drugs. It appears thus more likely to identify interesting compounds by searching for structural moieties related to a known activity, and then use a genomic- or LCMS guided screen to identify lead compounds. The latter was used to identify novel cyanobacterial cyclic peptides containing 4-methylproline, which has the ability to inhibit liver-transporters [91].

\subsubsection{Biosynthesis and genome based methods:}

The biosynthetic gene clusters of many cyanobacterial bioactive compounds have been revealed during the last 15 years, which have allowed for the development of new DNA based methods in order to predict the production of compounds [92-94]. These methods can be added into traditional bioactivity screening methods for finding new potential producers and identifying the producers of known toxic compounds. Both ribosomal and non-ribosomal biosynthetic pathways for cyanobacterial bioactive compounds have been described [95-97]. Cyanobacteria have shown to be a rich source of nonribosomal biosynthetic pathways along with the myxobacteria, pseudomonads and streptomycetes by using genome mining tools [97]. NRPS and PKS gene clusters are widely distributed in the cyanobacteria as well as ribosomal pathways occur commonly [97-99]. Genome mining reveals new insights into bioactive product discovery when gene clusters can be identified before knowing the target of activity [91, 98, 99]. This method can be used to find putative gene clusters and further attached to structural analysis to reveal the novel compounds. Genome based methods can unveil those compounds that are not detected in bioassay testing due to low amounts of bioactive compounds or inactive genes.

A high number of bioactive compounds have been found from cyanobacteria and those identified with anticancer activities represent a highly varied group of different chemical structures. Previously in our laboratories we have screened anti-leukemic compounds from cyanobacteria and found high frequency of interesting bioactivities [70, 77, 82]. In the following sections, we will re-analyze our findings from previous work together with additional new screening results, to reveal possible links between bioactivities and genus, sampling site and others, with emphasis on anti-leukemic activity. The results can be used as a guide to the search for novel anti-cancer compounds in future screening programs.

\section{MATERIALS AND METHOD}

\subsection{Cyanobacteria strains and extracts}

The cyanobacteria strains analyzed here were from Cyanobacterial Culture Collection of University of Helsinki (HAMBI) and were isolated from Baltic Sea cost areas, mainly in benthic habitats $[77,82]$ and some symbiotic strains were also used, mostly isolated from lichen Peltigera sp. [82] (Supplementary Table 1.). In addition, we have included unpublished data from strains collected from various locations including limnic habitats (Supplementary Table 1.). Cyanobacteria were identified using morphological methods [77] and/or sequencing of 16S rDNA genes [82]. Each strain was cultured in $\mathrm{Z} 8$ or $\mathrm{Z} 8 \mathrm{X}$ medium at $20^{\circ} \mathrm{C}$ under continuous light in $15 \mu \mathrm{mol} \mathrm{m}^{-2} \mathrm{~s}^{-1}[77,82]$. The cells grown 20-60 days in 3 liter volume of medium were harvested, freeze dried and extracted [77, 82]. We analyzed separately the aqueous and organic (methanol or 1:1 methanol:dichloromethane) extracts. 
The previously unpublished cyanobacteria strains were treated as in Liu et al. [82]. Cyanobacterial DNA was extracted using E.Z.N.A. SP Plant DNA Mini Kit (Omega Bio-Tek Inc.). The cells were first disrupted using twice FastPrep ${ }^{\mathrm{TM}}$ for $30 \mathrm{~s}$ at $6.5 \mathrm{~m} \mathrm{~s}^{-1}$ and then followed manufacturer's instructions in extraction protocol. The $16 \mathrm{~S}$ rRNA genes were amplified by PCR, cloned into pCR ${ }^{\circledR} 2.1$ vector and clones were sequenced and aligned as described before [100].

\subsection{Cell lines and cytotoxic assays}

Cyanobacterial extracts were tested for their ability to induce apoptosis in primary rat hepatocytes in suspension, and in the human AML cell line Molm13 (acute monocytic leukaemia with the poor prognostic factor FLT3 internal tandem duplication) [101] or the rat AML cell line IPC-81 (derived from the BNML, acute promyelocytic of neutrophil lineage) [102]. The primary rat hepatocytes were isolated by in vitro collagenase perfusion [103, 104]. Experimental conditions were as described in detail in [77]. Hepatocytes are particularly suited to detect variants of the common cyanotoxins microcystin and nodularin, which are specifically transported into the cells through the liver-specific transporter proteins OATP1B1 and 1B3. In some cases, we used HEK293T (Human embryonic kidney cells, ATCC no: CRL11268) transfected with OATP1B3 or 1B1 [105] to detect liver-selective toxins, and this has proven to be a reliable cellbased assay to detect such activity, and is also sensitive for variants not detected by LC-MS [82]. For cell death assays, cells were dissolved in fresh medium, added extracts in concentrations from 0.1 to $1 \%$ or the corresponding volume of solvent for control, incubated overnight together with extracts and results were assessed by microscopy as described before [82]. We eliminated adenosine effect detected in previous studies $[70,82]$ by using serum that was not heatinactivated to supplement the culturing medium. Such serum contains active adenosine deaminase, which converts adenosine to inactive inosine. Experiments on AML and HEK293T cells were performed in $0.1 \mathrm{~mL}$ in 96 well tissue culture plates, and the HEK293T cells were allowed to rest for $24 \mathrm{~h}$ to attach to the substratum before addition of extracts.

\subsection{LC-MS analysis of cyanobacterial extracts}

We further analyzed the extracts that showed cytotoxic activities with LC-MS, to detect any known cytotoxic compounds. Cyanobacteria were extracted similarly as for cytotoxic tests and LC-MS was performed on an Agilent 1100 Series LC-MSD TRAP System HPLC (Agilent Technologies, Palo Alto, CA, USA) with XCT Plus model ion trap mass detector. Ten microliters of samples were separated on a Luna C8-(2) column ( $150 \times 2 \mathrm{~mm}, 5 \mu \mathrm{m}$, Phenomenex, Torrance, CA, USA) eluted $0.15 \mathrm{ml} \mathrm{min}^{-1}$ with $0.1 \%$ aqueous $\mathrm{HCOOH}$ (A) and isopropanol $(+0.1 \% \mathrm{HCOOH})(B)$ starting from $5 \%$ $\mathrm{B}$ to $100 \% \mathrm{~B}$ in 35 minutes at $40^{\circ} \mathrm{C}$. Mass spectra were acquired using electrospray ionization in positive mode, Ultra Scan mode and scan range of $m / z, 200-1100$.

\section{RESULTS AND DISCUSSIONS}

\subsection{Summary of the new data included in the study}

Several studies have shown that cyanobacteria produce a great number of diverse apoptosis inducing compounds effective against leukemia cells $[70,77,79,82,106]$. The new unpublished results are in line with our previous findings [70, $77,82]$ showing divergent and high amount of apoptotic activities (Fig. 2). About $48 \%$ of these 43 cyanobacteria strains studied showed high (over $70 \%$ ) cell death activity toward either of the cells used, and $32 \%$ showed selective activity towards AML cell lines (Supplementary Table 2.). Organic extracts from samples HIID B16A, Microcystis sp. Izancya 30 and 7 stood out from other results by being highly cytotoxic towards all cell lines tested for. These extracts presented nonspecific activities. For our purpose, namely antiAML activity, strains like Trichormus sp. HIID D3, Anabaena sp. HIID D7A, Leptolyngbya sp. HIID D2A and HIID B21B were more interesting, showing high activity against Molm13 cells but less towards IPC-81 cells or hepatocytes.

Extracts of strains Nostoc sp. XHIID C2 and Calothrix sp. XPORK 9A showed strong activity towards Molm13 cells and moderate activity against IPC-81 cells, but were inactive towards hepatocytes. Similarly a group of Planktothrix sp. strains (Planktothrix sp. 18, 127, 251, 278, 289) showed high activity against Molm13 cells together with high or moderate activity against IPC-81 cells without hepatocyte activity. On the contrary Microcystis sp. Izancya 43 and 31 were active only against hepatocytes, suggesting the presence of microcystin or nodularin-like compounds. Only few strains showed activities in both aqueous and organic extracts. Organic extracts were altogether more active and the most of the strong activities were detected in organic extracts. One exception was the activity of the strain Nostoc sp. HIID D1B where the aqueous extract caused apoptosis in Molm13 wild type cell line as well as in hepatocytes. Overall, IPC-81 and Molm13 cells responded similarly to the cyanobacterial extracts but the Molm13 cell line seemed to be slightly more susceptible to cyanobacterial extracts (Fig. 3). We conclude that both cell lines can be used to detect anti-AML activity from cyanobacterial extract.

The studied cyanobacteria strains were identified based on the 16S rRNA gene sequencing and they were widely distributed in the phylogenetic tree (Supplementary Fig. 1.). The biggest studied genus group was Planktothrix sp. along with Microcystis sp. while other genera had one or two representatives. Especially some strains from Lake Hiidenvesi were found to have only few near neighbors. Some of these strains were showing only $93 \%$ similarity in BLAST searches (NCBI) but they were roughly named based on the BLAST searches and morphology. 


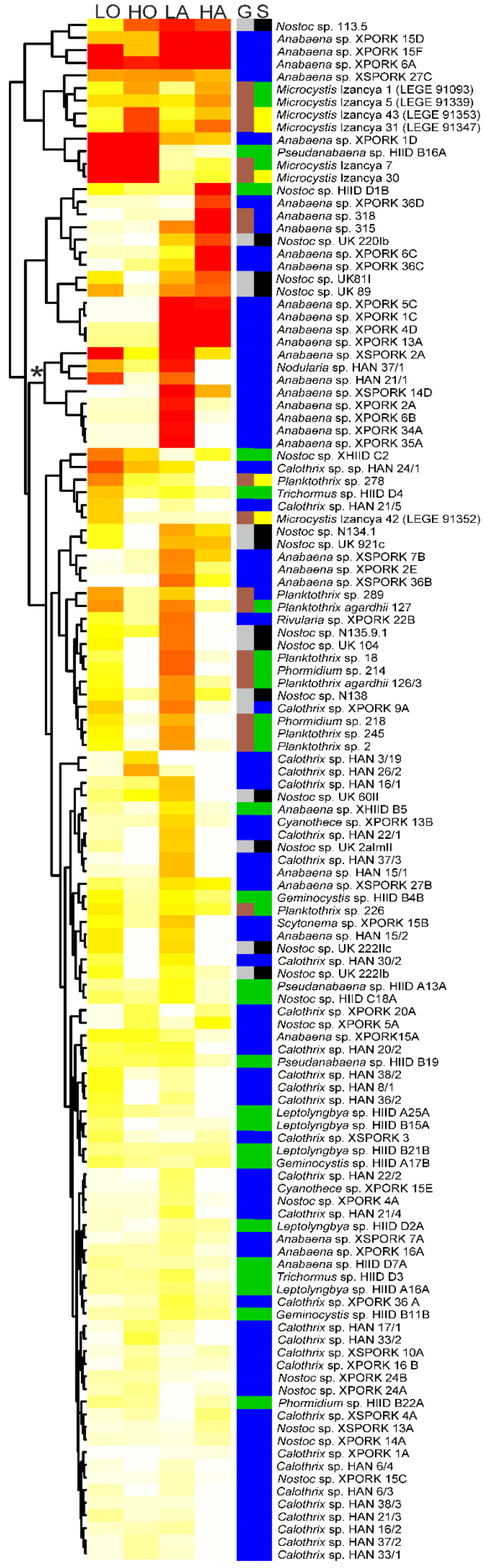

Fig. 2. The heat map with clustering analysis of all the four studies. $\mathrm{LO}=$ Leukemia cell death (IPC-81) in organic extracts $(\%) . \mathrm{HO}=$ Cell death activity (\%) against non-malignant cells (hepatocyte or HEK293T cells transfected with OTAP1B1 or 1B3) in organic extracts. $\mathrm{LA}=$ Leukemia cell death $($ IPC-81) in aqueous extracts. HA $=$ Cell death activity $(\%)$ against non-malignant cells (hepatocyte or HEK293T cells transfected with OTAP1B1 or 1B3) in aqueous extracts. The apoptotic activities are presented in darkening colors from white $(0 \%)$ to bright red $(100 \%)$. The heat map was clustered according to activities in $\mathrm{R}$ (version 3.1.1.) [107] by using function heatmap. 2 in package gplots [108]. $\mathrm{G}=$ Growth habitats of the strains (blue: benthic, green: sediment, brown: planktonic, grey: symbiotic). $\mathrm{S}=$ Sampling places of the strains (blue: Baltic Sea, black: terrestrial, green: lake, yellow: other limnic isolation places).

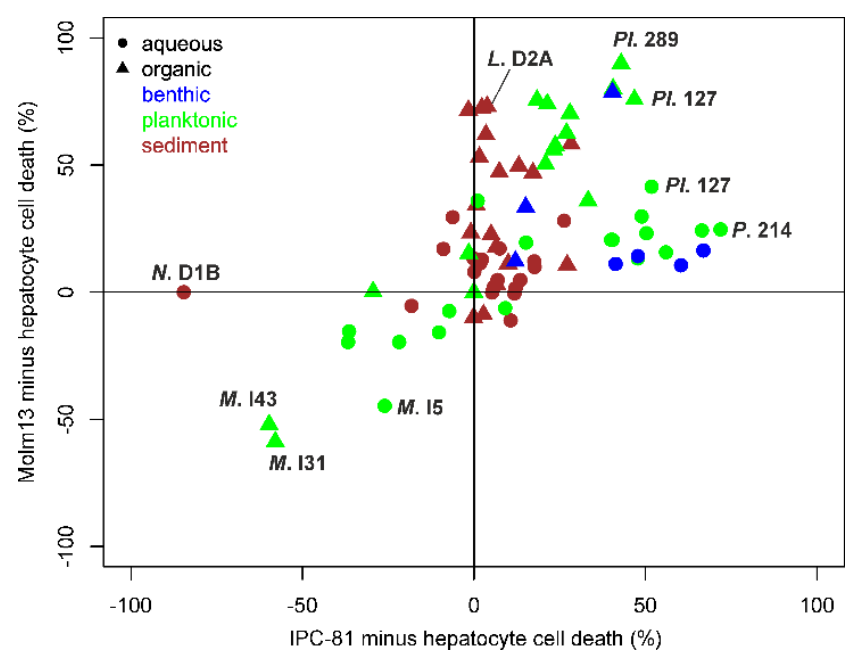

Fig. 3. The new unpublished data of IPC-81, Molm13 and hepatocyte cell death $(\%)$ caused by aqueous and organic extracts. The $\mathrm{x}$-axis is the IPC-81 cell death (\%) minus hepatocyte cell death (\%) and the yaxis is the Molm13 cell death (\%) reduced from hepatocyte cell death $(\%)$. The green planktonic, aqueous extracts such as Planktothrix sp. 127 (Pl. 127) and Phormidium sp. 214 (P. 214) were especially potential IPC-81 cell death inducers selectively as they were not active against hepatocytes. The organic extracts were more active against Molm13 cells and many organic sediment samples like Leptolyngbya sp. HIID D2A (L. D2A) was selectively active against Molm13 cells. Some organic extracts such as Planktothrix sp. 289 and 127 (Pl. 289, Pl. 127) were active for both AML cell lines, but they were slightly more active against Molm13 cells. In the other corner of the figure there are extracts that were selectively active against hepatocytes (Microcystis Izancya 43, 31 and 15 [M. I43, M. I31, $M$. I5]). In addition, the strains showing equal activities against IPC-81, Molm13 and hepatocyte cells come to the zero point. The aqueous extract of Nostoc sp. HIID D1B (N. D1B) was totally different from others by producing apoptosis against hepatocytes and Molm13 cells but not IPC-81 cells. 


\subsection{Different study cases provided similar results}

In this study, in addition to the summarized new results (in section 3.1.) we analyzed additional datasets from previous publications $[70,77,82]$ in order to reveal new aspects and improvements in the search for anti-leukemic activity from cyanobacteria strains. In general, the cyanobacterial extracts showed high content of bioactivity. The heat map illustrates the apoptosis inducing activity against the AML cell line IPC81 together with either primary hepatocytes or HEK293T cells transfected with OTAP1B1 or 1B3 of the four studies (Fig. 2). In the dataset of Herfindal et al. [77] and Oftedal et al. [70] 14 strains out of 43 showed high (above $70 \%$ ) anti-leukemic activity from which five strains exhibited a specific activity toward AML cells. From the study of Liu et al. [82] four strains out of 40 showed high activities, where two were selective towards AML cells. The new unpublished data included five strains with high AML-activity and two of them were specifically active against IPC-81 cell line. Although each study was separate and the starting point divergent from another the results were very similar. Together, these studies illustrate the potential of cyanobacteria in producing bioactive compounds that selectively induce apoptosis in AML cells. The results of these studies were not completely comparable due to the differences in methods. For instance, the extraction protocol differs, being a sequential extraction [70, 77] or a two-phase extraction [82]. Also, we now excluded activities such as adenosine-like activity from the two recent studies [82], which could explain the higher amount of activities in the first studies [70, 77].

The heat map illustrated clearly which strains were the most potent AML apoptosis inducers and the cluster of those specifically leukemia active strains was marked with an asterisk (Fig. 2). This group showed high activities against AML cells mainly in aqueous extracts. Even though a few of these strains contained adenosine like activity, most of the strains had bioactivity where we could not identify the compound by cell-activity or LC-MS. In addition, there were potential strains in other clusters. One example is the organic extract of Planktothrix sp. 251, which produced high and cytotoxic activity selectively against AML cells. An interesting result was that neither we could easily pick a genera or a sampling place according to the cluster analysis to guide us in the search for anti-leukemic compounds. It thus appeared that all genera studied contained strains that were potent producers of anti-AML activity, and that a future search for novel bioactivity should not be narrowed down to one or two genera. On the contrary, a broad approach appears to be the best in order to detect many different activities.

In the studies of Herfindal et al. [77] and Oftedal et al. [70] the most of the strains belonged to the genus Anabaena which was acknowledged to be fruitful. All of the potent anti-AML inducers were Anabaena strains, to mention but a few Anabaena sp. XPORK 2A, XPORK 6B, XPORK 35A and XSPORK 14D were specifically active against AML cells. The two latter studies [82] included several other genera, such as Calothrix, Nodularia and Planktothrix. Interestingly, the most potent anti-AML strains in the study of Liu et al. [82] were Nodularia sp. HAN 37/1 and Anabaena sp. HAN 21/1 which were almost only representatives of these genera in that study. Only one Calothrix strain, Calothrix sp. HAN 24/1, showed high anti-AML apoptosis. In addition, the Nostoc sp. strains showed high apoptotic activities in the study of Liu et al. [82] but the most of these strains were shown to produce either microcystins or adenosines or both and thus they were active against hepatocytes or OATP-expressing HEK293T cell line. The new unpublished data included the most variable range of genera and the most potent anti-AML inducers were detected from various strains including Planktothrix, Calothrix, Nostoc, Trichormus, Anabaena and Leptolyngbya subspecies. The new unpublished data thus added many new potential genera along the Anabaena and Nodularia. However, when screening natural samples and especially cyanobacteria the strain identification and isolation to pure culture is still a time consuming and difficult task, which is often conducted in parallel with, or after testing of the crude extracts for bioactivities. This makes it harder to select samples based on genus and guides the decision-making even further to the sampling places and sampling times.

The cyanobacteria were isolated from planktonic, benthic and sediment habitats of limnic or brackish water environments, in addition to symbiotic strains collected from lichen (Fig. 2.). The largest part of the strains were benthic cyanobacteria from the Baltic Sea collected from various substrates (Fig. 2.), since these are little investigated with respect to bioactivity compared to planktonic bloom forming species. Symbiotic strains, which were all from genus Nostoc, seemed to be less potent producers of anti-AML activity, and many of them produced microcystin- and adenosine-like activities (Fig. 2.). The benthic habitats harbored many interesting activities, for instance the benthic Baltic Sea strains from the studies of Herfindal et al. [77] and Oftedal et al. [70] as well as strains isolated from sediment of Lake Hiidenvesi showed specific anti-AML activity or specific activity solely against Molm13 cell line. The benthic strains seemed to be overall more interesting targets while many of the planktonic cyanobacteria were shown to produce hepatotoxins. Fig. 3 illustrates how the majority of the hepatocyte-toxic extracts in the new unpublished dataset were planktonic cyanobacterial extracts. However, some of the planktonic strains also showed specific activities against AML cell lines, for instance Planktothrix sp. strains were apoptotic against IPC-81 cells.

Data from the first studies $[70,77]$ showed that the antileukemic activities of cyanobacterial extracts resided mainly in the aqueous extracts, however we concluded later that also the adenosine activity was present in the aqueous extracts. Still we could detect anti-leukemic activities in aqueous extracts after removing the adenosine activity. As shown in Fig. 2 anti-AML activity resides in both extracts, but usually in either of the extract, rather than in both extract from one strain. This suggests that the anti-AML activity detected in the screenings derive from structurally different compounds with different chemical properties. Again, this underscores the ability of cyanobacteria to produce diverse bioactive compounds. The most potent AML apoptosis inducing samples in the study of Liu et al. [82] were the organic extract of the strain Anabaena sp. HAN 21/1 and the aqueous extract of the strain Nodularia sp. 37/1. However, the presence of bioactivity in certain extract depends simply on the used solvents thus only results from similar methods should be compared in concern of the extracts. The change of the 
extraction method from three-phase extraction to faster twophase extraction method did not decrease the amount of potential findings. Each extract of cyanobacteria contained all the compounds dissolved in solvents. This meant that extracts included several compounds, which were interacting and could inhibit or enhance each other. Thus extracts may contain more than one bioactive compound and the screening results against a set of cell lines can vary although the main bioactive compound is same in different extracts.

\subsection{LC-MS analysis enhance the results of cell assays}

A selection of the active samples was further analyzed by LC-MS to detect known cytotoxic compounds. In ten of the nineteen strains studied, no such compounds were found, even among the most potent apoptosis inducers like Pseudanabaena sp. HIID B16A. This underscores the potential of discovering novel bioactive compounds in cyanobacteria from culture collections. Several compound groups were however found (Fig. 4.), such as anabaenopeptins, hassallidins, putative microviridins and microcystins, which were present in the aqueous extraction phase. Compounds like aeruginosins, putative cyanobactins and depsipeptides resided in both phases. Cyanobactins were prenylated and nonprenylated. We found no clear correlation between the peptide groups and cytotoxicity data. For instance, the aqueous extract of Planktothrix sp. 289 and organic extract of Nostoc sp. HIID D1B exhibited no activities in cell tests and no compounds could be recognized by LCMS, whereas the aqueous extract of Planktothrix sp. 251 and 278 exhibited no activities in cell tests but several peptide groups were present. The organic extracts of Planktothrix sp. 289 and 278 extracts in addition to aqueous extract of Nostoc sp. HIID D1B showed however $100 \%$ activity against Molm13 cells but different peptide groups (hassallidins, cyanobactins, aeruginosins) were present in the extracts. It is thus possible that for each extracts, one or several unknown compounds were responsible for the cytotoxic activity, or that the active compound(s) belonged to these peptide groups.

The aqueous extract of strain HIID D1B was active against AML cells and hepatocytes, and we could detect the presence of the recently discovered antifungal compound hassallidin, whose effect on mammalian cells is not yet described [109, 110]. In addition, some of the strains (XPORK 5C, XSPORK 7B, XSPORK 36B) with cytotoxic activity, have been found to produce hassallidin variants and hassallidin appears to be produced by many cyanobacteria [111]. It is thus possible that hassallidin activity was present in these extracts, and it should be further investigated if hassallidin caused the cytotoxic response, and if so, how hassallidins affect mammalian cell signaling.

The hepatotoxic microcystins and nodularins induce apoptosis selectively in primary hepatocytes due to the presence of the organic anion transporter polypeptides (OATP) 1B1 and 1B3 [112]. We found that particularly the aqueous extracts showed strong apoptotic activity towards either primary hepatocytes, or HEK293T cells with enforced expression of OATP1B1/1B3 [77, 82]. In the study of Herfindal et al. [77] two planktonic cyanobacteria expressed strong apoptosis-inducing activity selectively towards primary hepatocytes, with morphology consistent with microcystin or nodularin induced apoptosis [73, 77, 113].
These showed strong activity in aqueous extracts and moderate activity in methanol extract against hepatocytes but had low cytotoxicity towards the AML-cell lines IPC-81 and HL-60. However, we have demonstrated that microcystins producing strains fail to induce primary hepatocyte apoptosis due to the presence of cyclic peptide antitoxins $[105,114]$. In the last dataset, several of the strains were known to contain microcystins, but some did not produce apoptosis in OATP1B1/1B3 expressing cells or primary hepatocytes. We concluded that this was due to the presence of cyclic peptide antitoxins [91, 105]. Also the LC-MS analyses supported the notion that cyanobacteria produce many different active agents. For instance from the organic extract of Planktothrix sp. 245 we found two different preliminary structures of oscillarins and depsipeptides together with cyanobactins and anabaenopeptins in addition to small amount of the microcystins (de-Me-MC-RR).
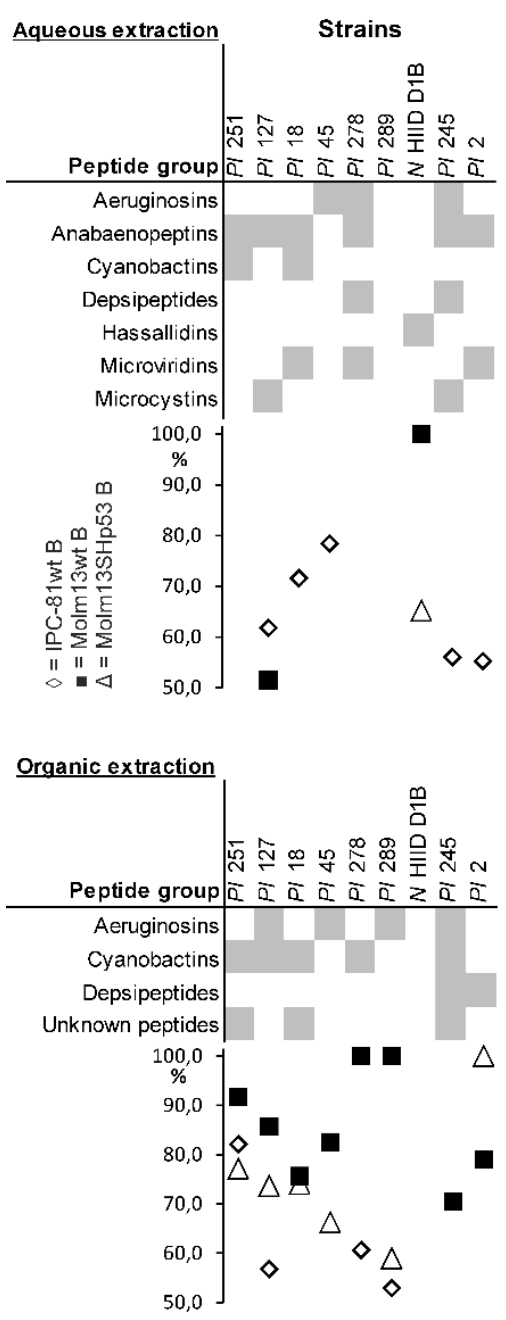

Fig. 4. Occurrence of the cyanobacterial peptide groups and AML activity. $\square=$ Dominant peptide groups in aqueous and organic extracts, $P l=$ Planktothrix sp., $N=$ Nostoc $\mathrm{sp}$. 


\subsection{Cytotoxicity screens leads to identification of novel anti-AML compounds}

Screening of culture collections gives the foundation to discover novel bioactive compounds from a great amount of strains. Some of the studied cytotoxic strains from the studies of Herfindal et al. [77] and Oftedal et al. [70] induced intriguing apoptosis morphology and they were later found to contain the novel compounds anabaenolysin A and B [115]. Anabaenolysins induce lysis of cells by targeting cholesterol containing membranes [116]. In total eight of these cytotoxic strains were identified to produce anabaenolysin A or B, Anabaena sp. XSPORK $27 \mathrm{C}$ and $15 \mathrm{~F}$ being the most potent producers [115]. However, extracts from producers of anabaenolysins behaved differently; XPORK $15 \mathrm{~F}$ extracts were active against all cell lines tested, but extracts from the strain Anabaena sp. XSPORK 2A were mainly active against IPC-81 cells. This underlines the diversity of bioactive compounds in cyanobacteria, and how a mixture of bioactivities can influence the outcome of simple cell based assays. It seems therefore reasonable to consider all extracts with bioactivity as potent producers of anti AML activity, and conclude after for instance a crude fractionation of the extracts is performed.

The strain Anabaena sp. HAN 21/1, which was screened in the study of Liu et al. [82], was recently detected to produce several variants of scytophycins [117]. This strain was detected to have specific and high antileukemic activity in both aqueous and organic extracts suggesting that scytophycins were the source of the detected activity. As more cyanobacteria strains are screened and compounds are identified it is unavoidable to rediscover "old" compounds. Still, even old compounds can reveal new aspects if they are tested in a new manner. For instance hierridin B was isolated from Cyanobium sp. on the basis of activity against colorectal adenocarcinoma cell line [118]. However, hierridin B had been previously described as a mild antiplasmodial compound [119]. On the contrary scytophycins have been described as cytotoxic compounds from beginning [120,121].

\subsection{Concluding remarks}

With this review of new and previous data, we demonstrate the potency of cyanobacterial culture collections as source for novel compounds with a desired bioactivity, in this case anti-AML activity. Although Anabaena species from the Baltic Sea appeared to be the best producers of activity selective towards AML cells, most of the studied genera had one or more representatives with such activity. Moreover, benthic, planktonic and symbiotic cyanobacteria were represented with the desired activity, but the benthic strains were the most potent producers. It appears that bioactive compounds can be found in virtually all cyanobacteria, irrespective of genera, sampling site or habitat. Perhaps more importantly, the bioactivity is present even after several years in culture, as previously demonstrated in a study where a strain retained the bioactivity after more than 50 years in culture [79]. Even though there is an ever-increasing chance for rediscovery of known compounds, our preliminary LCMS screens failed to identify known compounds from several of the active strains, showing that cyanobacteria produce still unknown secondary metabolites which may have valuable features in drug discovery. These novel metabolites may be used also in combination with known drugs to improve disease treatment. One option is therefore to include known drugs in the screens to detect activities that increase the AML cell response to commonly used cytostatics such as daunorubicin or AraC. The new structures and mechanisms of action can also be used for development of new drugs.

Here we added yet another group of cyanobacteria samples into the studies of anti-leukemic compounds from cyanobacteria and detected a variable cytotoxic features varying from generic cytotoxicity to AML specific activities. We found a variable set of strains which should be further examined to reveal the active compounds in extracts. Together this clearly supports the maintenance of culture collections for future screening programs also for other activities than anticancer.

\section{CONFLICT OF INTEREST}

The authors confirm that this article content has no conflicts of interest.

\section{ACKNOWLEDGEMENTS}

This study was supported by Academy project grant (258827) from the Academy of Finland to K.S., and from the Norwegian Cancer Society to L.H. and Western Norway Regional Health Authorities to L.H. and R.B. Nina Lied Larsen is acknowledged for maintaining the AML cell lines used in this study. A.H. is student at the Doctoral Programme in Microbiology and Biotechnology.

\section{SUPPLEMENTARY MATERIAL}

Supplementary Table 1. Information of the strains used to screen anti-leukemic activities.

Supplementary Table 2. The new unpublished results of cell death induced by cyanobacterial aqueous and organic extracts against IPC-81, Molm13 and hepatocyte cells.

Supplementary Fig. 1. The 16S rRNA gene tree of the new unpublished strains.

\section{REFERENCES}

[1] Rowe, J. M. Important milestones in acute leukemia in 2013. Best Practice \& Research Clinical Haematology, 2013, 26(3), 10.1016/j.beha.2013.10.002.

[2] Newman, D. J.; Cragg, G. M.; Snader, K. M. Natural products as sources of new drugs over the period 1981-2002. J. Nat. Prod., 2003, 66(7), 10.1021/np0300961.

[3] Lam, K. S. New aspects of natural products in drug discovery. Trends Microbiol., 2007, 15(6), 10.1016/j.tim.2007.04.001.

[4] Singh, R. K.; Tiwari, S. P.; Rai, A. K.; Mohapatra, T. M. Cyanobacteria: an emerging source for drug discovery. J. Antibiot., 2011, 64(6), 10.1038/ja.2011.21.

[5] Castenholz, R. W., Ed. Bergey`s Manual of Systematic Bacteriology vol.1, 2 ed.; Springer: New York, USA, 2001.

[6] Whitton, B. A.; Potts, M., Eds. Ecology of Cyanobacteria II, the diversity in space and time; Springer: London, UK, 2012.

[7] Sivonen, K.; Jones, G. In Cyanobacterial Toxins; Chorus, I., Bartram, J., Eds.; Toxic cyanobacteria in water; E \& FN Spon: London, UK, 1999, pp. 41-111.

[8] Burja, A. M.; Banaigs, B.; Abou-Mansour, E.; Burgess, J. G.; Wright, P. C. Marine cyanobacteria - a prolific source of natural 
products. Tetrahedron, 2001, 57(46), 10.1016/S00404020(01)00931-0.

[9] Nunnery, J. K.; Mevers, E.; Gerwick, W. H. Biologically active secondary metabolites from marine cyanobacteria. Curr. Opin. Biotechnol., 2010, 21(6), 10.1016/j.copbio.2010.09.019.

[10] Gerwick, W. H.; Moore, B. S. Lessons from the past and charting the future of marine natural products drug discovery and chemical biology. Chem. Biol., 2012, 19(1), 10.1016/j.chembiol.2011.12.014.

[11] Welker, M.; von Döhren, H. Cyanobacterial peptides - nature's own combinatorial biosynthesis. FEMS Microbiol. Rev., 2006, 30(4), 10.1111/j.1574-6976.2006.00022.x.

[12] Sivonen, K.; Leikoski, N.; Fewer, D. P.; Jokela, J. Cyanobactinsribosomal cyclic peptides produced by cyanobacteria. Appl. Microbiol. Biotechnol., 2010, 86(5), 10.1007/s00253-010-2482-x.

[13] Arnison, P. G.; Bibb, M. J.; Bierbaum, G.; Bowers, A. A.; Bugni, T. S.; Bulaj, G.; Camarero, J. A.; Campopiano, D. J.; Challis, G. L.; Clardy, J.; Cotter, P. D.; Craik, D. J.; Dawson, M.; Dittmann, E.; Donadio, S.; Dorrestein, P. C.; Entian, K.; Fischbach, M. A.; Garavelli, J. S.; Goeransson, U.; Gruber, C. W.; Haft, D. H.; Hemscheidt, T. K.; Hertweck, C.; Hill, C.; Horswill, A. R.; Jaspars, M.; Kelly, W. L.; Klinman, J. P.; Kuipers, O. P.; Link, A. J.; Liu, W.; Marahiel, M. A.; Mitchell, D. A.; Moll, G. N.; Moore, B. S.; Mueller, R.; Nair, S. K.; Nes, I. F.; Norris, G. E.; Olivera, B. M.; Onaka, H.; Patchett, M. L.; Piel, J.; Reaney, M. J. T.; Rebuffat, S.; Ross, R. P.; Sahl, H.; Schmidt, E. W.; Selsted, M. E.; Severinov, K.; Shen, B.; Sivonen, K.; Smith, L.; Stein, T.; Suessmuth, R. D.; Tagg, J. R.; Tang, G.; Truman, A. W.; Vederas, J. C.; Walsh, C. T.; Walton, J. D.; Wenzel, S. C.; Willey, J. M.; van der Donk, W. A. Ribosomally synthesized and post-translationally modified peptide natural products: overview and recommendations for a universal nomenclature. Nat. Prod. Rep., 2013, 30(1), 10.1039/c2np20085f.

[14] Ersmark, K.; Del Valle, J. R.; Hanessian, S. Chemistry and biology of the aeruginosin family of serine protease inhibitors. Angewandte Chemie-International Edition, 2008, 47(7), 10.1002/anie.200605219.

[15] Liu, L.; Jokela, J.; Wahlsten, M.; Nowruzi, B.; Permi, P.; Zhang, Y. Z.; Xhaard, H.; Fewer, D. P.; Sivonen, K. Nostosins, trypsin inhibitors isolated from the terrestrial cyanobacterium Nostoc sp. strain FSN. J. Nat. Prod., 2014, 77(8), 10.1021/np500106w.

[16] Tan, L. T. Pharmaceutical agents from filamentous marine cyanobacteria. Drug Discov. Today, 2013, 18(17-18), 10.1016/j.drudis.2013.05.010.

[17] Zanchett, G.; Oliveira-Filho, E. C. Cyanobacteria and cyanotoxins: from impacts on aquatic ecosystems and human health to anticarcinogenic effects. Toxins, 2013, 5(10), 10.3390/toxins5101896.

[18] Flahive, E.; Srirangam, J. In The Dolastatins; CRC Press: 2011, pp. 263-290.

[19] Pettit, G. R.; Kamano, Y.; Fujii, Y.; Herald, C. L.; Inoue, M.; Brown, P.; Gust, D.; Kitahara, K.; Schmidt, J. M.; Doubek, D. L.; Michel, C. Anti-neoplastic agents. 72. Marine animal biosynthetic constituents for cancer-chemotherapy. J. Nat. Prod., 1981, 44(4), 10.1021/np50016a016.

[20] Harrigan, G. G.; Yoshida, W. Y.; Moore, R. E.; Nagle, D. G.; Park, P. U.; Biggs, J.; Paul, V. J.; Mooberry, S. L.; Corbett, T. H.; Valeriote, F. A. Isolation, structure determination, and biological activity of dolastatin 12 and lyngbyastatin I from Lyngbya majuscula Schizothrix calcicola cyanobacterial assemblages. J. Nat. Prod., 1998, 61(10), 10.1021/np9801211.

[21] Luesch, H.; Moore, R. E.; Paul, V. J.; Mooberry, S. L.; Corbett, T. $\mathrm{H}$. Isolation of dolastatin 10 from the marine cyanobacterium Symploca species VP642 and total stereochemistry and biological evaluation of its analogue symplostatin 1. J. Nat. Prod., 2001, 64(7), $10.1021 / \mathrm{np} 010049 \mathrm{y}$.

[22] Pettit, G. R.; Kamano, Y.; Herald, C. L.; Tuinman, A. A.; Boettner, F. E.; Kizu, H.; Schmidt, J. M.; Baczynskyj, L.; Tomer, K. B.; Bontems, R. J. Antineoplastic agents. 136. The isolation and structure of a remarkable marine animal antineoplastic constituent dolastatin 10. J. Am. Chem. Soc., 1987, 109(22), 10.1021/ja00256a070

[23] Pettit, G. R.; Kamano, Y.; Dufresne, C.; Cerny, R. L.; Herald, C. L.; Schmidt, J. M. Antineoplastic agents. 187. Isolation and structure of the cytostatic linear depsipeptide dolastatin-15. J. Org. Chem., 1989, 54(26), 10.1021/jo00287a003.
[24] Deng, C.; Pan, B.; O'Connor, O. A. Brentuximab vedotin. Clinical Cancer Research, 2013, 19(1), 10.1158/1078-0432.CCR-12-0290.

[25] Mayer, A. M. S. The Global Marine Pharmaceuticals Pipeline Available from: http://marinepharmacology.midwestern.edu/ (Accessed May 9, 2015)

[26] Trimurtulu, G.; Ohtani, I.; Patterson, G. M. L.; Moore, R. E.; Corbett, T. H.; Valeriote, F. A.; Demchik, L. Total structures of cryptophycins, potent antitumor depsipeptides from the blue-green alga Nostoc sp. strain GSV 224. J. Am. Chem. Soc., 1994, 116(11), 10.1021/ja00090a020

[27] Smith, C. D.; Zhang, X. Q.; Mooberry, S. L.; Patterson, G. M. L.; Moore, R. E. Cryptophycin - a new antimicrotubule agent active against drug-resistant cells. Cancer Res., 1994, 54(14).

[28] Edelman, M. J.; Gandara, D. R.; Hausner, P.; Israel, V.; Thornton, D.; DeSanto, J.; Doyle, L. A. Phase 2 study of cryptophycin 52 (LY355703) in patients previously treated with platinum based chemotherapy for advanced non-small cell lung cancer. Lung Cancer, 2003, 39(2), 10.1016/S0169-5002(02)00511-1.

[29] Weiss, C.; Sammet, B.; Sewald, N. Recent approaches for the synthesis of modified cryptophycins. Nat. Prod. Rep., 2013, 30(7), 10.1039/c3np70022d.

[30] Verma, V. A.; Pillow, T. H.; DePalatis, L.; Li, G.; Phillips, G. L.; Polson, A. G.; Raab, H. E.; Spencer, S.; Zheng, B. The cryptophycins as potent payloads for antibody drug conjugates. Bioorg. Med. Chem. Lett., 2015, 25(4), 10.1016/j.bmcl.2014.12.070.

[31] Blokhin, A. V.; Yoo, H. D.; Geralds, R. S.; Nagle, D. G.; Gerwick, W. H.; Hamel, E. Characterization of the interaction of the marine cyanobacterial natural product curacin-a with the colchicine site of tubulin and initial structure-activity studies with analogs. Mol. Pharmacol., 1995, 48(3).

[32] Gerwick, W. H.; Proteau, P. J.; Nagle, D. G.; Hamel, E.; Blokhin, A.; Slate, D. L. Structure of curacin-a, a novel antimitotic, antiproliferative, and brine shrimp toxic natural product from the marine cyanobacterium Lyngbya majuscula. J. Org. Chem., 1994, 59(6), 10.1021/jo00085a006.

[33] Wipf, P.; Reeves, J. T.; Balachandran, R.; Giuliano, K. A.; Hamel, E.; Day, B. W. Synthesis and biological evaluation of a focused mixture library of analogues of the antimitotic marine natural product curacin A. J. Am. Chem. Soc., 2000, 122(39), 10.1021/ja002213u.

[34] Lu, Y.; Chen, J.; Xiao, M.; Li, W.; Miller, D. D. An overview of tubulin inhibitors that interact with the colchicine binding site. Pharm. Res., 2012, 29(11), 10.1007/s11095-012-0828-z.

[35] Teruya, T.; Sasaki, H.; Fukazawa, H.; Suenaga, K. Bisebromoamide, a potent cytotoxic peptide from the marine cyanobacterium Lyngbya sp.: isolation, stereostructure, and biological activity. Org. Lett., 2009, 11(21), 10.1021/o19020546.

[36] Sumiya, E.; Shimogawa, H.; Sasaki, H.; Tsutsumi, M.; Yoshita, K.; Ojika, M.; Suenaga, K.; Uesugi, M. Cell-morphology profiling of a natural product library identifies bisebromoamide and miuraenamide a as actin filament stabilizers. Acs Chemical Biology, 2011, 6(5), $10.1021 / \mathrm{cb} 1003459$.

[37] Suzuki, K.; Mizuno, R.; Suenaga, K.; Teruya, T.; Tanaka, N.; Kosaka, T.; Oya, M. Bisebromoamide, an extract from Lyngbya species, induces apoptosis through ERK and mTOR inhibitions in renal cancer cells. Cancer Medicine, 2013, 2(1), 10.1002/cam4.53.

[38] Luesch, H.; Yoshida, W. Y.; Moore, R. E.; Paul, V. J.; Corbett, T. $\mathrm{H}$. Total structure determination of apratoxin A, a potent novel cytotoxin from the marine cyanobacterium Lyngbya majuscula. $J$. Am. Chem. Soc., 2001, 123(23), 10.1021/ja010453j.

[39] Luesch, H.; Yoshida, W. Y.; Moore, R. E.; Paul, V. J. New apratoxins of marine cyanobacterial origin from Guam and Palau. Bioorg. Med. Chem., 2002, 10(6), 10.1016/S0968-0896(02)000147.

[40] Gutierrez, M.; Suyama, T. L.; Engene, N.; Wingerd, J. S.; Matainaho, T.; Gerwick, W. H. Apratoxin D, a potent cytotoxic cyclodepsipeptide from Papua New Guinea collections of the marine cyanobacteria Lyngbya majuscula and Lyngbya sordida. J. Nat. Prod., 2008, 71(6), 10.1021/np800121a.

[41] Luesch, H.; Chanda, S. K.; Raya, R. M.; DeJesus, P.; Orth, A. P.; Walker, J. R.; Belmonte, J. C. I.; Schultz, P. G. A functional genomics approach to the mode of action of apratoxin A. Nature Chemical Biology, 2006, 2(3), 10.1038/nchembio769. 
[42] Liu, Y.; Law, B. K.; Luesch, H. Apratoxin A reversibly inhibits the secretory pathway by preventing cotranslational translocation. Mol. Pharmacol., 2009, 76(1), 10.1124/mol.109.056085.

[43] Shen, S.; Zhang, P.; Lovchik, M. A.; Li, Y.; Tang, L.; Chen, Z.; Zeng, R.; Ma, D.; Yuan, J.; Yu, Q. Cyclodepsipeptide toxin promotes the degradation of Hsp90 client proteins through chaperone-mediated autophagy. J. Cell Biol., 2009, 185(4), 10.1083/jcb.200810183.

[44] Chen, Q.; Liu, Y.; Luesch, H. Systematic chemical mutagenesis identifies a potent novel apratoxin A/E hybrid with improved in vivo antitumor activity. Acs Medicinal Chemistry Letters, 2011, 2(11), $10.1021 / \mathrm{ml} 200176 \mathrm{~m}$

[45] Chen, Q.; Liu, Y.; Cai, W.; Luesch, H. Improved total synthesis and biological evaluation of potent apratoxin S4 based anticancer agents with differential stability and further enhanced activity. J. Med. Chem., 2014, 57(7), 10.1021/jm4019965.

[46] Nogle, L. M.; Gerwick, W. H. Somocystinamide A, a novel cytotoxic disulfide dimer from a Fijian marine cyanobacterial mixed assemblage. Org. Lett., 2002, 4(7), 10.1021/ol017275j.

[47] Wrasidlo, W.; Mielgo, A.; Torres, V. A.; Barbero, S.; Stoletov, K.; Suyama, T. L.; Klemke, R. L.; Gerwick, W. H.; Carson, D. A.; Stupack, D. G. The marine lipopeptide somocystinamide A triggers apoptosis via caspase 8. Proc. Natl. Acad. Sci. U. S. A., 2008, 105(7), 10.1073/pnas.0712198105.

[48] Sato, S.; Murata, A.; Orihara, T.; Shirakawa, T.; Suenaga, K.; Kigoshi, H.; Uesugi, M. Marine natural product aurilide activates the OPA1-mediated apoptosis by binding to prohibitin. Chem. Biol., 2011, 18(1), 10.1016/j.chembiol.2010.10.017

[49] Suenaga, K.; Mutou, T.; Shibata, T.; Itoh, T.; Kigoshi, H.; Yamada, $\mathrm{K}$. Isolation and stereostructure of aurilide, a novel cyclodepsipeptide from the Japanese sea hare Dolabella auricularia. Tetrahedron Lett., 1996, 37(37), 10.1016/S0040-4039(96)01464-5.

[50] Suenaga, K.; Mutou, T.; Shibata, T.; Itoh, T.; Fujita, T.; Takada, N.; Hayamizu, K.; Takagi, M.; Irifune, T.; Kigoshi, H.; Yamada, K. Aurilide, a cytotoxic depsipeptide from the sea hare Dolabella auricularia: isolation, structure determination, synthesis, and biological activity. Tetrahedron, 2004, 60(38), 10.1016/j.tet.2004.06.125.

[51] Tripathi, A.; Puddick, J.; Prinsep, M. R.; Rottmann, M.; Chan, K. P.; Chen, D. Y.; Tan, L. T. Lagunamide C, a cytotoxic cyclodepsipeptide from the marine cyanobacterium Lyngbya $\begin{array}{llll}\text { majuscula. } & \text { Phytochemistry, } & \text { 2011, }\end{array}$ 10.1016/j.phytochem.2011.08.019.

[52] Tripathi, A.; Fang, W.; Leong, D. T.; Tan, L. T. Biochemical studies of the lagunamides, potent cytotoxic cyclic depsipeptides from the marine cyanobacterium Lyngbya majuscula. Marine Drugs, 2012, 10(5), 10.3390/md10051126.

[53] Tripathi, A.; Puddick, J.; Prinsep, M. R.; Rottmann, M.; Tan, L. T. Lagunamides A and B: cytotoxic and antimalarial cyclodepsipeptides from the marine cyanobacterium Lyngbya majuscula. J. Nat. Prod., 2010, 73(11), 10.1021/np100442x.

[54] Ying, Y.; Taori, K.; Kim, H.; Hong, J.; Luesch, H. Total synthesis and molecular target of largazole, a histone deacetylase inhibitor. $J$. Am. Chem. Soc., 2008, 130(26), 10.1021/ja8013727.

[55] Bowers, A.; West, N.; Taunton, J.; Schreiber, S. L.; Bradner, J. E.; Williams, R. M. Total synthesis and biological mode of action of largazole: A potent class I histone deacetylase inhibitor. J. Am. Chem. Soc., 2008, 130(33), 10.1021/ja8033763.

[56] Quintas-Cardama, A.; Santos, F. P. S.; Garcia-Manero, G. Histone deacetylase inhibitors for the treatment of myelodysplastic syndrome and acute myeloid leukemia. Leukemia, 2011, 25(2), 10.1038/leu.2010.276

[57] Taori, K.; Paul, V. J.; Luesch, H. Structure and activity of largazole, a potent antiproliferative agent from the Floridian marine cyanobacterium Symploca sp. J. Am. Chem. Soc., 2008, 130(6), 10.1021/ja710064S0002-7863(71)01006-0.

[58] Liu, Y.; Salvador, L. A.; Byeon, S.; Ying, Y.; Kwan, J. C.; Law, B. K.; Hong, J.; Luesch, H. Anticolon cancer activity of largazole, a marine-derived tunable histone deacetylase inhibitor. J. Pharmacol. Exp. Ther., 2010, 335(2), 10.1124/jpet.110.172387.

[59] Hong, J.; Luesch, H. Largazole: From discovery to broad-spectrum therapy. Nat. Prod. Rep., 2012, 29(4), 10.1039/c2np00066k.

[60] Liu, Y.; Wang, Z.; Wang, J.; Lam, W.; Kwong, S.; Li, F.; Friedman, S. L.; Zhou, S.; Ren, Q.; Xu, Z.; Wang, X.; Ji, L.; Tang, S.; Zhang,
H.; Lui, E. L.; Ye, T. A histone deacetylase inhibitor, largazole, decreases liver fibrosis and angiogenesis by inhibiting transforming growth factor-beta and vascular endothelial growth factor signalling. Liver International, 2013, 33(4), 10.1111/liv.12034.

[61] Zhou, H.; Jiang, S.; Chen, J.; Ren, X.; Jin, J.; Su, S. B. Largazole, an inhibitor of class I histone deacetylases, attenuates inflammatory corneal neovascularization. Eur. J. Pharmacol., 2014, 740, 10.1016/j.ejphar.2014.06.019.

[62] Pereira, A. R.; Kale, A. J.; Fenley, A. T.; Byrum, T.; Debonsi, H. M.; Gilson, M. K.; Valeriote, F. A.; Moore, B. S.; Gerwick, W. H. The carmaphycins: new proteasome inhibitors exhibiting an alpha, betaepoxyketone warhead from a marine cyanobacterium. Chembiochem, 2012, 13(6), 10.1002/cbic.201200007.

[63] Trivella, D. B. B.; Pereira, A. R.; Stein, M. L.; Kasai, Y.; Byrum, T.; Valeriote, F. A.; Tantillo, D. J.; Groll, M.; Gerwick, W. H.; Moore, B. S. Enzyme inhibition by hydroamination: design and mechanism of a hybrid carmaphycin-syringolin enone proteasome inhibitor. Chem. Biol., 2014, 21(6), 10.1016/j.chembiol.2014.04.010.

[64] Linington, R. G.; Edwards, D. J.; Shuman, C. F.; McPhail, K. L.; Matainaho, T.; Gerwick, W. H. Symplocamide A, a potent cytotoxin and chymotrypsin inhibitor from the marine cyanobacterium Symploca sp. J. Nat. Prod., 2008, 71(1), 10.1021/np070280x.

[65] Stolze, S. C.; Meltzer, M.; Ehrmann, M.; Kaiser, M. Solid phase total synthesis of the 3-amino-6-hydroxy-2-piperidone (Ahp) cyclodepsipeptide and protease inhibitor symplocamide A. Chemical Communications, 2010, 46(46), 10.1039/c0cc02889d.

[66] Gunasekera, S. P.; Ross, C.; Paul, V. J.; Matthew, S.; Luesch, H. Dragonamides $\mathrm{C}$ and $\mathrm{D}$, linear lipopeptides from the marine cyanobacterium brown Lyngbya polychroa. J. Nat. Prod., 2008, 71(5), 10.1021/np0706769.

[67] Kang, H.; Krunic, A.; Shen, Q.; Swanson, S. M.; Orjala, J. Minutissamides A-D, antiproliferative cyclic decapeptides from the cultured cyanobacterium Anabaena minutissima. J. Nat. Prod., 2011, 74(7), 10.1021/np2002226.

[68] Quintana, J.; Bayona, L. M.; Castellanos, L.; Puyana, M.; Camargo, P.; Aristizabal, F.; Edwards, C.; Tabudravu, J. N.; Jaspars, M.; Ramos, F. A. Almiramide D, cytotoxic peptide from the marine cyanobacterium Oscillatoria nigroviridis. Bioorg. Med. Chem., 2014, 22(24), 10.1016/j.bmc.2014.10.039.

[69] Sanchez, L. M.; Lopez, D.; Vesely, B. A.; Della Togna, G.; Gerwick, W. H.; Kyle, D. E.; Linington, R. G. Almiramides A-C: discovery and development of a new class of leishmaniasis lead compounds. $J$. Med. Chem., 2010, 53(10), 10.1021/jm100265s.

[70] Oftedal, L.; Selheim, F.; Wahlsten, M.; Sivonen, K.; Doskeland, S. O.; Herfindal, L. Marine benthic cyanobacteria contain apoptosisinducing activity synergizing with daunorubicin to kill leukemia cells, but not cardiomyocytes. Marine Drugs, 2010, $8(10)$ $10.3390 / \mathrm{md} 8102659$.

[71] Gantar, M.; Dhandayuthapani, S.; Rathinavelu, A. Phycocyanin induces apoptosis and enhances the effect of topotecan on prostate cell line LNCaP. Journal of Medicinal Food, 2012, 15(12), 10.1089/jmf.2012.0123.

[72] Harvey, A. L.; Edrada-Ebel, R.; Quinn, R. J. The re-emergence of natural products for drug discovery in the genomics era. Nature Reviews Drug Discovery, 2015, 14(2), 10.1038/nrd4510.

[73] Fladmark, K. E.; Serres, M. H.; Larsen, N. L.; Yasumoto, T.; Aune, T.; Doskeland, S. O. Sensitive detection of apoptogenic toxins in suspension cultures of rat and salmon hepatocytes. Toxicon, 1998 , 36(8), 10.1016/S0041-0101(98)00083-X.

[74] Herfindal, L.; Kasprzykowski, F.; Schwede, F.; Lankiewicz, L.; Fladmark, K. E.; Lukomska, J.; Wahlsten, M.; Sivonen, K.; Grzonka, Z.; Jastorff, B.; Doskeland, S. O. Acyloxymethyl esterification of nodularin-R and microcystin-LA produces inactive protoxins that become reactivated and produce apoptosis inside intact cells. J. Med. Chem., 2009, 52(18), 10.1021/jm900502e.

[75] Shoemaker, R. H. The NCI60 human tumour cell line anticancer drug screen. Nature Reviews Cancer, 2006, 6(10), 10.1038/nrc1951.

[76] Developmental Therapeutics Program, National Cancer Institute and National Institute of Health. Screening Services: NCI-60 DTP human tumor cell line screen. Available from: http://dtp.nci.nih.gov/branches/btb/ivclsp.html (Accessed May 3, 2015).

[77] Herfindal, L.; Oftedal, L.; Selheim, F.; Wahlsten, M.; Sivonen, K.; Doskeland, S. O. A high proportion of Baltic Sea benthic 
cyanobacterial isolates contain apoptogens able to induce rapid death of isolated rat hepatocytes. Toxicon, 2005, 46(3), 10.1016/j.toxicon.2005.04.005

[78] Myhren, L. E.; Nygaard, G.; Gausdal, G.; Sletta, H.; Teigen, K.; Degnes, K. F.; Zahlsen, K.; Brunsvik, A.; Bruserud, O.; Doskeland, S. O.; Selheim, F.; Herfindal, L. Iodinin (1,6-dihydroxyphenazine 5,10-dioxide) from Streptosporangium sp. induces apoptosis selectively in myeloid leukemia cell lines and patient cells. Marine Drugs, 2013, $11(2), 10.3390 /$ md1 1020332.

[79] Oftedal, L.; Skjaerven, K. H.; Coyne, R. T.; Edvardsen, B.; Rohrlack, T.; Skulberg, O. M.; Doskeland, S. O.; Herfindal, L. The apoptosis-inducing activity towards leukemia and lymphoma cells in a cyanobacterial culture collection is not associated with mouse bioassay toxicity. J. Ind. Microbiol. Biotechnol., 2011, 38(4), 10.1007/s10295-010-0791-9.

[80] Silva-Stenico, M. E.; Kaneno, R.; Zambuzi, F. A.; Vaz, M. G. M. V.; Alvarenga, D. O.; Fiore, M. F. Natural products from cyanobacteria with antimicrobial and antitumor activity. Curr. Pharm. Biotechnol., 2013, 14(9).

[81] Costa, M.; Garcia, M.; Costa-Rodrigues, J.; Costa, M. S.; Ribeiro, M. J.; Fernandes, M. H.; Barros, P.; Barreiro, A.; Vasconcelos, V.; Martins, R. Exploring bioactive properties of marine cyanobacteria isolated from the Portuguese coast: high potential as a source of anticancer compounds. Marine Drugs, 2014, 12(1), 10.3390/md12010098.

[82] Liu, L.; Herfindal, L.; Jokela, J.; Shishido, T. K.; Wahlsten, M.; Doskeland, S. O.; Sivonen, K. Cyanobacteria from terrestrial and marine sources contain apoptogens able to overcome chemoresistance in acute myeloid leukemia cells. Marine Drugs, 2014, 12(4), 10.3390/md12042036.

[83] Konickova, R.; Vankova, K.; Vanikova, J.; Vanova, K.; Muchova, L.; Subhanova, I.; Zadinova, M.; Zelenka, J.; Dvorak, A.; Kolar, M.; Strnad, H.; Rimpelova, S.; Ruml, T.; Wong, R. J.; Vitek, L. Anticancer effects of blue-green alga Spirulina platensis, a natural source of bilirubin-like tetrapyrrolic compounds. Annals of Hepatology, 2014, 13(2).

[84] Kyadari, M.; Fatma, T.; Velpandian, T.; Malliga, P.; Bharat, N.; Bano, F. Antiangiogenic and antiproliferative assessment of cyanobacteria. Indian. J. Exp. Biol., 2014, 52(8).

[85] Gausdal, G.; Gjertsen, B. T.; McCormack, E.; Van Damme, P.; Hovland, R.; Krakstad, C.; Bruserud, O.; Gevaert, K.; Vandekerckhove, J.; Doskeland, S. O. Abolition of stress-induced protein synthesis sensitizes leukemia cells to anthracycline-induced death. Blood, 2008, 111(5), 10.1182/blood-2007-07-103242.

[86] Prestegard, S. K.; Oftedal, L.; Coyne, R. T.; Nygaard, G.; Skjaerven, K. H.; Knutsen, G.; Doskeland, S. O.; Herfindal, L. Marine benthic diatoms contain compounds able to induce leukemia cell death and modulate blood platelet activity. Marine Drugs, 2009, 7(4), 10.3390/md7040605.

[87] Tanaka, Y.; Yoshihara, K.; Tsuyuki, M.; Kamiya, T. Apoptosis induced by adenosine in human leukemia HL-60 cells. Exp. Cell Res., 1994, 213(1), 10.1006/excr.1994.1196.

[88] Mooberry, S. L.; Stratman, K.; Moore, R. E. Tubercidin stabilizes microtubules against vinblastine-induced depolymerization, a taxollike effect. Cancer Lett., 1995, 96(2), 10.1016/03043835(95)03940-X.

[89] Annesley, C. E.; Brown, P. Novel agents for the treatment of childhood acute leukemia. Therapeutic advances in hematology, 2015, 6(2), 10.1177/2040620714565963.

[90] El-Elimat, T.; Zhang, X.; Jarjoura, D.; Moy, F. J.; Orjala, J.; Kinghorn, A. D.; Pearce, C. J.; Oberlies, N. H. Chemical diversity of metabolites from fungi, cyanobacteria, and plants relative to FDAapproved anticancer agents. Acs Medicinal Chemistry Letters, 2012, $3(8), 10.1021 / \mathrm{ml} 300105 \mathrm{~s}$

[91] Liu, L.; Jokela, J.; Herfindal, L.; Wahlsten, M.; Sinkkonen, J.; Permi, P.; Fewer, D. P.; Doskeland, S. O.; Sivonen, K. 4-Methylproline guided natural product discovery: co-occurrence of 4-hydroxy- and 4-methylprolines in nostoweipeptins and nostopeptolides. Acs Chemical Biology, 2014, 9(11), 10.1021/cb500436p.

[92] Tillett, D.; Dittmann, E.; Erhard, M.; von Döhren, H.; Borner, T.; Neilan, B. A. Structural organization of microcystin biosynthesis in Microcystis aeruginosa PCC7806: an integrated peptide-polyketide synthetase system. Chem. Biol., 2000, 7(10), 10.1016/S10745521(00)00021-1.
[93] Rouhiainen, L.; Paulin, L.; Suomalainen, S.; Hyytiainen, H.; Buikema, W.; Haselkorn, R.; Sivonen, K. Genes encoding synthetases of cyclic depsipeptides, anabaenopeptilides, in Anabaena strain 90. Mol. Microbiol., 2000, 37(1), 10.1046/j.13652958.2000.01982.x

[94] Rantala-Ylinen, A.; Kana, S.; Wang, H.; Rouhiainen, L.; Wahlsten, M.; Rizzi, E.; Berg, K.; Gugger, M.; Sivonen, K. Anatoxin-a synthetase gene cluster of the cyanobacterium Anabaena sp. strain 37 and molecular methods to detect potential producers. Appl. Environ. Microbiol., 2011, 77(20), 10.1128/AEM.06022-11.

[95] Sivonen, K.; Leikoski, N.; Fewer, D. P.; Jokela, J. Cyanobactinsribosomal cyclic peptides produced by cyanobacteria. Appl. Microbiol. Biotechnol., 2010, 86(5), 10.1007/s00253-010-2482-x.

[96] Wang, H.; Fewer, D. P.; Sivonen, K. Genome mining demonstrates the widespread occurrence of gene clusters encoding bacteriocins in cyanobacteria. Plos One, 2011, 6(7), 10.1371/journal.pone.0022384.

[97] Wang, H.; Fewer, D. P.; Holm, L.; Rouhiainen, L.; Sivonen, K. Atlas of nonribosomal peptide and polyketide biosynthetic pathways reveals common occurrence of nonmodular enzymes. Proc. Natl. Acad. Sci. U. S. A., 2014, 111(25), 10.1073/pnas.1401734111.

[98] Shih, P. M.; Wu, D.; Latifi, A.; Axen, S. D.; Fewer, D. P.; Talla, E.; Calteau, A.; Cai, F.; de Marsac, N. T.; Rippka, R.; Herdman, M.; Sivonen, K.; Coursin, T.; Laurent, T.; Goodwin, L.; Nolan, M.; Davenport, K. W.; Han, C. S.; Rubin, E. M.; Eisen, J. A.; Woyke, T.; Gugger, M.; Kerfeld, C. A. Improving the coverage of the cyanobacterial phylum using diversity-driven genome sequencing. Proc. Natl. Acad. Sci. U. S. A., 2013, 110(3), 10.1073/pnas.1217107110.

[99] Leikoski, N.; Liu, L.; Jokela, J.; Wahlsten, M.; Gugger, M.; Calteau, A.; Permi, P.; Kerfeld, C. A.; Sivonen, K.; Fewer, D. P. Genome mining expands the chemical diversity of the cyanobactin family to include highly modified linear peptides. Chem. Biol., 2013, 20(8), 10.1016/j.chembiol.2013.06.015.

[100] Shishido, T. K.; Kaasalainen, U.; Fewer, D. P.; Rouhiainen, L. Jokela, J.; Wahlsten, M.; Fiore, M. F.; Yunes, J. S.; Rikkinen, J.; Sivonen, K. Convergent evolution of [D-leucine(1)] microcystin-LR in taxonomically disparate cyanobacteria. Bmc Evolutionary Biology, 2013, 13, 10.1186/1471-2148-13-86.

[101] Matsuo, Y.; MacLeod, R. A. F.; Uphoff, C. C.; Drexler, H. G.; Nishizaki, C.; Katayama, Y.; Kimura, G.; Fujii, N.; Omoto, E.; Harada, M.; Orita, K. Two acute monocytic leukemia (AML-M5a) cell lines (MOLM-13 and MOLM-14) with interclonal phenotypic heterogeneity showing MLL-AF9 fusion resulting from an occult chromosome insertion, ins(11;9)(q23;p22p23). Leukemia, 1997, $11(9), 10.1038 /$ sj.leu.2400768.

[102] Lacaze, N.; Gombaudsaintonge, G.; Lanotte, M. Conditions controlling long-term proliferation of brown Norway rat promyelocytic leukemia invitro - primary growth-stimulation by microenvironment and establishment of an autonomous brown Norway leukemic stem-cell line. Leuk. Res., 1983, 7(2), 10.1016/0145-2126(83)90005-X.

[103] Seglen, P. O. Preparation of isolated rat liver cells. Methods Cell Biol., 1976, 13, 10.1016/S0091-679X(08)61797-5.

[104] Mellgren, G.; Vintermyr, O. K.; Doskeland, S. O. Okadaic acid, cAMP, and selected nutrients inhibit hepatocyte proliferation at different stages in $G(1)$ - modulation of the cAMP effect by phosphatase inhibitors and nutrients. J. Cell. Physiol., 1995, 163(2), $10.1002 /$ jcp. 1041630203.

[105] Herfindal, L.; Myhren, L.; Kleppe, R.; Krakstad, C.; Selheim, F.; Jokela, J.; Sivonen, K.; Doskeland, S. O. Nostocyclopeptide-M1: a potent, nontoxic inhibitor of the hepatocyte drug transporters OATP1B3 and OATP1B1. Molecular Pharmaceutics, 2011, 8(2), $10.1021 / \mathrm{mp} 1002224$.

[106] Selheim, F.; Herfindal, L.; Martins, R.; Vasconcelos, V.; Doskeland, S. O. Neuro-apoptogenic and blood platelet targeting toxins in benthic marine cyanobacteria from the Portuguese coast. Aquatic Toxicology, 2005, 74(4), 10.1016/j.aquatox.2005.06.005.

[107] R Core Team R: A language and environment for statistical computing. R Foundation for Statistical Computing, Vienna, Austria. Available from: http://www.R-project.org/.

[108] Warnes, G. R.; Bolker, B.; Bonebakker, L., et al. Various R programming tools for plotting data. Available from: http://CRAN.R-project.org/package=gplots. 
[109] Neuhof, T.; Schmieder, P.; Preussel, K.; Dieckmann, R.; Pham, H.; Bartl, F.; von Döhren, H. Hassallidin A, a glycosylated lipopeptide with antifungal activity from the cyanobacterium Hassallia sp. J. Nat. Prod., 2005, 68(5), 10.1021/np049671r.

[110] Neuhof, T.; Schmieder, P.; Seibold, M.; Preussel, K.; von Döhren, H. Hassallidin B - second antifungal member of the hassallidin family. Bioorg. Med. Chem. Lett., 2006, 16(16), 10.1016/j.bmcl.2006.05.094.

[111] Vestola, J.; Shishido, T. K.; Jokela, J.; Fewer, D. P.; Aitio, O.; Permi, P.; Wahlsten, M.; Wang, H.; Rouhiainen, L.; Sivonen, K. Hassallidins, antifungal glycolipopeptides, are widespread among cyanobacteria and are the end-product of a nonribosomal pathway. Proc. Natl. Acad. Sci. U. S. A., 2014, 111(18), 10.1073/pnas.1320913111.

[112] Hagenbuch, B.; Meier, P. J. The superfamily of organic anion transporting polypeptides. Biochimica Et Biophysica ActaBiomembranes, 2003, 1609(1), 10.1016/S0005-2736(02)00633-8.

[113] Krakstad, C.; Herfindal, L.; Gjertsen, B. T.; Boe, R.; Vintermyr, O. K.; Fladmark, K. E.; Doskeland, S. O. CaM-kinasell-dependent commitment to microcystin-induced apoptosis is coupled to cell budding, but not to shrinkage or chromatin hypercondensation. Cell Death Differ., 2006, 13(7), 10.1038/sj.cdd.4401798.

[114] Jokela, J.; Herfindal, L.; Wahlsten, M.; Permi, P.; Selheim, F.; Vasconcelos, V.; Doskeland, S. O.; Sivonen, K. A novel cyanobacterial nostocyclopeptide is a potent antitoxin against microcystins. $\quad$ Chembiochem, $2010, \quad$ 11(11), 10.1002/cbic. 201000179

[115] Jokela, J.; Oftedal, L.; Herfindal, L.; Permi, P.; Wahlsten, M.; Doskeland, S. O.; Sivonen, K. Anabaenolysins, novel cytolytic lipopeptides from benthic Anabaena cyanobacteria. Plos One, 2012, 7(7), 10.1371/journal.pone.0041222.
[116] Oftedal, L.; Myhren, L.; Jokela, J.; Gausdal, G.; Sivonen, K.; Doskeland, S. O.; Herfindal, L. The lipopeptide toxins anabaenolysin A and B target biological membranes in a cholesteroldependent manner. Biochimica Et Biophysica Acta-Biomembranes, 2012, 1818(12), 10.1016/j.bbamem.2012.07.015.

[117] Shishido, T. K.; Humisto, A.; Jokela, J.; Wahlsten, M.; Tamrakar A.; Fewer, D. P.; Permi, P.; Andreote, A. P. D.; Fiore, M. F.; Sivonen, K. Antifungal compounds from cyanobacteria. Marine Drugs, 2015, 13(4), 2124-2140.

[118] Leao, P. N.; Costa, M.; Ramos, V.; Pereira, A. R.; Fernandes, V. C.; Domingues, V. F.; Gerwick, W. H.; Vasconcelos, V. M.; Martins, R. Antitumor activity of hierridin b, a cyanobacterial secondary metabolite found in both filamentous and unicellular marine strains. Plos One, 2013, 8(7), 10.1371/journal.pone.0069562.

[119] Papendorf, O.; Konig, G. M.; Wright, A. D. Hierridin B and 2,4 dimethoxy-6-heptadecyl-phenol, secondary metabolites from the cyanobacterium Phormidium ectocarpi with antiplasmodial activity Phytochemistry, 1998, 49(8), 10.1016/S0031-9422(98)00440-3.

[120] Ishibashi, M.; Moore, R.; Patterson, G.; Xu, C.; Clardy, J. Scytophycins, cytotoxic and antimycotic agents from the Cyanophyte Scytonema pseudohofmanni. J. Org. Chem., 1986, 51(26), 10.1021/jo00376a047.

[121] Moore, R.; Patterson, G.; Mynderse, J.; Barchi, J.; Norton, T.; Furusawa, E.; Furusawa, S. Toxins from cyanophytes belonging to the Scytonemataceae. Pure and Applied Chemistry, 1986, 58(2), $10.1351 /$ pac198658020263. 